Received: 28/6/2019

UDK: 376-056.45:303.682

Original scientific paper

\title{
SOCIOMETRIC STATUS OF GIFTED STUDENTS IN GLASSROOM AND SUBJEGT TEACHING IN ELEMENTARY SCHOOL
}

Sanela Mužar Horvat

OŠ Hinka Juhna Podgorač

smuzar1@gmail.com 


\section{ABSTRACT}

Gifted individuals are those with extraordinary abilities unlike their peers. Poor sociometric status of gifted students often stems from the dissatisfaction of their educational needs and the fact that their interests often do not coincide with those of their peers. Research has shown that the popularity and popularity of students in a peer group is important for success in the future. The aim of this empirical study was to determine the sociometric status of potential perceived gifted students in the classroom and subject teaching. The sample were 59 students of the elementary and subject classes in rural areas in the Osijek - Baranja County. The results of the study showed that there is a strong and positive correlation between sociometric status and the number of nominations in different areas of academic achievement, and it was found that students who were found to have potential perceived giftedness had a higher sociometric status than children who were not identified as potential perceived giftedness. The results of the research could provide guidance for checking previous theoretical assumptions and supplementing existing key factors that influence the sociometric status of students in the educational system. Also, this research could be an impetus for future research in this area.

Keywords: gifted students, sociometric status, peer relations, class and subject teaching 


\section{INTRODUCTION}

The media and the internet bring a variety of stories about children with above average abilities, who are different from other children. Looking deeper below the surface of the topic itself, there are many questions. One question is how to approach such children, how parents treat gifted children, whether parents provide adequate education with respect to their abilities, what school as an educational institution does for such students. The questions are whether gifted children are excluded from school, society, what the state can do for them, and whether time at certain institutions is dedicated to them at all so that they can develop their potential and be involved in the identification process. There are many questions that just lead us to the conclusion of the complexity of this topic. Gifted students as well as their peers feel the need to be accepted and to belong to groups and communicate. They strive for popularity in society and seek companionship and communication. They often progress faster than average individuals because they are much better at learning and mastering teaching material than average individuals, and they are often preoccupied with reading, researching and engaging in many extracurricular activities. They are often not accepted in society precisely because of their characteristics, and they do not fit into usual school expectations. Because of their greater needs than average individuals, the environment fails to give them enough attention, so they go unnoticed and fall short of what they need to grow their potential and thrive. Gifted students in a group with their peers form social skills and develop a self-image. Determination of sociometric status and acceptance of gifted students can be verified by examining sociometric status. Sociometry testing seeks to determine the group dynamics of the class (cohesion, i.e. group affiliation). Sociometry can consist of a positive and a negative criterion. The positive criterion gives us positive nominations (e.g. who the students want to sit with), while the negative criterion receives negative nominations (who the students do not want to sit with). In school setting, when children become students, social contact with peers develops in the classroom moral, intellectual and social progress. Although many gifted children have slightly higher social intelligence, they are accepted and easily find friends among peers, but this is usually not the case. There is a large number of gifted children who are unaccepted and fail to achieve good social relations with peers, are unhappy and rejected. The reason for the poorer sociometric status of the gifted is often found in the fact that their interests are not the same as those of their peers and their educational requirements have not been adequately met. 


\subsection{Sociometry}

Sociometry can be defined as a method which measures relationships of a group based on data or parameters. Sociometry methodology was developed by the American psychologist Moreno. Moreno (1962) by sociometry implies social science, psychological theory, and an empirical method of studying a group that helps to regulate and explore relationships between people. Cohen, Manion, Marrison (2007, according to Kolak, 2010) interpret that sociometry has several functions that define it as: a research technique that serves to study the functioning of a group, a diagnostic procedure to determine the position of an individual in a group, and the position of the group in the wider community, and a psychotherapy technique that helps an individual or group to better adapt. Moreno and his students believe that problematic situations in society can be solved not through class distribution, but by moving people because of emotional preferences. In order to obtain reliable data, not only the results of sociometry are important but it is necessary to collect preliminary information about the study group, prepare questions and conduct a sociometric survey and analyse and interpret the data received during the interview. Participation in a social study is voluntary. The answers should be honest because they will relate to the emotional side of the relationship in the team. The sociometry process is not difficult, but rules and norms must be followed. The aim of sociometry is to measure the structure of the human group.

The sociometric procedure examines the relationships within the group and consists of the fact that the group members choose other members of the group according to the set criteria, and based on their answers a picture is formed about the structure of the group and the place of individual members within that group. Sociometric techniques are implemented in clearly defined groups, e.g. classrooms or sports teams, because everyone in the group knows each other and knows the characteristics of all group members. One of the sociometric techniques is the technique of choosing or nomination in which there are two criteria for choosing: positive and negative criteria. The sociometric technique provides information about group relationships, relationships within a group, not individuals. In the positive criterion, the respondent selects a certain number of group members who they would prefer to participate in one of the foreseen situations with e.g. ask the student to choose the number of peers in the class he would most like to (sit, hang out, go out, etc.). In the case of a negative criterion, the respondent selects a certain number of members of the group who they would never want to participate in any of the foreseen situations with e.g. ask the student to choose the number of peers in the class he would never (write homework with, sit in a bench with, etc ...). 
The respondent should list the names of the group members he or she has chosen so that he or she writes the group name or surname, or they will circle the names on the list he / she has been given. How many members of the group will be indicated depends on the type of testing being conducted. It is easiest to specify or limit the choice to a number, then if more than one name is given, it is useful for the examiner to indicate to the respondent his or her first choice. The positive and negative criteria make it possible to obtain an acceptance index (shows how much acceptance of a member in the group) and a rejection index (indicates how much rejection of a member in the group) and then a liking index that takes into account the acceptance and rejection index. The rating scale is also a technique for measuring sociometric status. It consists of assessing the names of all members of the group on a graded rating scale. The number 1-5 determines the degree of liking (e.g. 1 = I don't like it at all, $5=$ I really like it). For example, a student evaluates a student in his or her class, and sociometric status gives the average that the student receives from all students in the class. Sociometric test data are presented in three ways: a sociometric matrix, a sociogram and a sociometric index. A sociometric matrix is a table listing all choices of a sociometric questionnaire. A sociogram is a pictorial representation between group members. The sociometric index represents how quantitatively the data on the structure of a group is obtained.

\subsection{Definitions of giftedness}

Giftedness is a term we often encounter. Giftedness, talent and creativity are not the same concepts, but they are often identified. Differentiating these concepts contributes to a better identification of gifted students and more effective work with them. Winner (2005) uses the term giftedness to describe children with three atypical characteristics: premature development, insistence that they play on their own, passion for mastery. Marland (1972, according to Ford Inman, Kirchner, 2016) defines gifted and talented children as gifted children with outstanding opportunities for high achievement in a gift report.

This report listed 6 areas of giftedness: general intellectual ability, special scientific stand, creative or productive thinking, leadership ability, visual performance skills, and psychomotor skills. According to Koren (1989) giftedness is a trait that enables an individual to consistently achieve a markedly above average performance in one or more activities. Giftedness includes manner and quality of thinking and memory, creativity, social adaptability, artistic sensitivity, some mechanical abilities, physical dexterity. Criteria related to giftedness are most often the intellect, creativity and interaction of highly developed abilities where creativ- 
ity is perceived as curiosity, imagination and intelligence for the area of a child's interest. Individuals who have developed one or more abilities significantly above average are considered gifted in one or the other (Koren, 1989). Defining giftedness tells us that the criteria mentioned are different: intellect, creativity, and the interaction of highly developed abilities. Creativity that is perceived by external signs (curiosity, imagination, intelligence) can be stimulated in various ways in areas for which gifted children show interest. It is necessary to distinguish giftedness from creativity. Giftedness is more innate than creativity. Creativity depends more on motivation and environment. The modern concept of giftedness encompasses not only highly developed abilities, but also intrinsic motivation for high achievement, that is, creativity. Creativity is manifested in innovative behaviour, that is, in the production of innovation in different areas of human activity (Pastuović, 1997). The inclusion of creativity trait in the concept of giftedness is unjustified for several reasons. The first is that there are highly intelligent (gifted) people who are not innovative (creative). There are persons who are not highly intelligent (gifted), but the main disadvantage of the concept of giftedness that includes creativity is that creativity is manifested in production or behaviour, which is conditioned not only by the person's characteristics but also by the characteristics of the environment in which he or she is (Pastuović, 1997).

\subsection{Social and emotional characteristics of gifted children}

According to Ford Inman, Kirchner (2016), the characteristics and traits of gifted children that distinguish them from their peers are traits of self-confidence, stubbornness, and frequent self-dissatisfaction. The general characteristics of gifted children are curiosity and thoughtfulness, seeing things differently, processing information faster than other children, and remembering details longer than their peers. This is followed by the social and emotional needs of gifted children, in which we distinguish social characteristics: facial expression, interpretation of the emotions of other gifted students when interacting with peers and adults, in class or in interaction with family. Emotional traits are linked as interpersonal awareness, such as the capacity to recognize one's emotions, motivations, and needs. Emotional needs can be demonstrated through individual levels of self-esteem, motivation to learn, or the ability to persevere in difficult tasks. Each child is unique with varying traits, gifts, talents and dispositions. Social and emotional traits are just one step that can help us identify the gifted. Teachers need to know the characteristics of the gifted at the very beginning of identification which can make their work with the gifted easier. Baily (2007) explains that gifted students are bored in 
classes and most often disagree with others. He also thinks that they are too critical of themselves and others, have no patience for others and are perfectionists. According to Robinson (2008) gifted students are more mature than their peers in spheres such as friendships, interest for games, social knowledge, behaviour and personalities. Robinson (2008) considers that although the degree of maturity may not match their maturity in the intellectual domain, gifted children show greater personal maturity than their peers.

Gifted students face a range of situations that pose a source of risk to their emotional and social development. Some of these situations are: intellectual and social progress compared to peers, inappropriate teaching pace with regard to their learning and understanding, tensions created by their ambition, energy, intensity of work compared to peers, negation of their abilities for the purpose of belonging to a group of peers. Robinson (2008) also highlights some of the myths that gifted children are often labelled with, such as: gifted children are nerds, are clumsy and socially ill, gifted children can choose any profession in the future and be successful, their acceleration destroys life, have poor social relationships in the family, etc.

\subsection{Difficulty of gifting children in social and emotional relationships}

According to Bailey (2007), the difficulties faced by gifted individuals are most often pressure from their peers and concern for acceptance in society. In times of adolescence and identity development, gifted individuals most often seek to conceal talent in order to better integrate with their peers. They often try to hide their talent by pretending to know less than they really do. Robinson (2008) interprets that in early childhood gifted children begin to attend preschools, but they are worried by the fact that their peers do not enjoy the same complex games, do not read books, and do not like games with complex rules. Faced with this problem, gifted children most often try to find a friend in their parents. Robinson (2008) also believes that gifted children have needs as well as their peers, but they also have needs that are understandable only to them. They need friends whom they can socialize and share common interests with. The problem arises because gifted children are much more advanced in development than their peers, so it is much harder for them to find friends who share the same interests as they do. When they become bored in a game, they most often withdraw from the game, which often causes their peers to be confused. Gifted children deal with stress in social relationships in a very unusual way. Asher and Fontaine (1990, according to Gommans, 2010) find that the influence of peer relationships becomes more 
important as children get into them and undergo adolescence. Numerous studies have shown that children with a negative sociometric status are more likely to show social and emotional problems. Sociometric status is also associated with loneliness. Children who have difficulties with their peers show a greater degree of loneliness and dissatisfaction (LaFontana and Cillessen, 2002).

\subsection{Review of relevant research}

The study by LaFontan et al. (2002) shows that children have mixed evaluative reactions to popular and unpopular peers. In both studies presented, children associated prosocial and antisocial behaviour with popularity. In the first study, antisocial behaviour was more strongly associated with popularity than with unpopularity, while in the second study, there was no difference in the level of antisocial behaviour attributed to popular and unpopular peers. In both studies, there were differences in negative correlates of popularity and unpopularity. Popular peers were seen as physically aggressive, while unpopular were seen as socially isolated. Children focus on quantity, not quality of interaction to determine popularity. The results also show that talent and ability are important determinants of popularity. Participants described the popular as attractive and athletic, while the unpopular were described as unattractive. The thinking of the participants is that they share their opinion of popularity according to the consensual view as a function of dominance, not of will. Children at this age look at popularity by position in the social hierarchy. Gender is also an important moderator of popularity. In both studies, children's perceptions varied depending on the gender, age, nationality of the participants.

Wentzel (2003) conducted a study examining sixth grade students' relationships between sociometric status and school adjustment. Ways in which sociometric status is associated with school adjustment through motivation were also examined. The aim was to explore the developmental importance of peer acceptance as they attend school. Wentzel (2003) considers sociometric status to be related to school adjustment in the form of social and academic competences. Coie, Dodge, \& Kupersmidt (1990, according to Wentzel, 2003) find that rejected children still tend to have peer rejection in the future, while other sociometric statuses are temporary. Students in the popular sociometric group are prosocial, those in the unpopular sociometric group are less aggressive and less indulgent, more motivated and indulgent are neglected, the controversial sociometric group is less indulgent and more aggressive compared to the average sociometric group.

Peairs (2010) conducted a study examining group differences in adolescents who were gifted and those who were not gifted in their relationship with peers 
such as sociometric status and friendship. In order to examine the sociometric status, participants needed to express an opinion whether they liked the student. The results showed that gifted students had a higher sociometric status than those who were not gifted. He also mentions the results of a second group of gifted students who, unlike the first group, were rejected and abused. The research has shown that there are disparities in the determination of the giftedness of students, which, given the status were popular and gifted students, who, despite the giftedness, were still unpopular.

The research of Košir and Pečjak (2005) examined the relationship between sociometric and peer relations of Slovenian students of different grades. The difference in the relationship between sociometric and peer popularity was also examined. The second purpose of the research was to investigate the difference between the notions of popularity and the characteristics of some students. The results show that peer popularity is a construct different from sociometric popularity. Popularity and sociometric popularity are similar constructs in elementary school, whereas in high school they are unrelated.

Mikas (2017) analyzed the interplay between school achievement, gender, and sociometric status of upper elementary school students. The survey included 427 students. The results indicate that gender and sociometric status have a significant effect on overall school performance independently, since the interaction between them is not statistically significant. Female students have significantly better school achievement than male students. The results confirmed the significant correlation between school achievement and adolescent social competence. Popular adolescents achieve the best academic achievement, followed by controversial and isolated, and poorest educational outcomes have a group of rejected adolescents. If we look at the results with gender in mind, the poorest academic achievement is achieved by discarded students (boys), who represent the most at-risk part of the student population, both in terms of school achievement and in terms of developing social competence.

The Maksić (1998) study was conducted to provide inconsistent evidence on the relationship of gifted adolescents with peers. The study shows that no significant differences were found between gifted and average groups of students in sociability, quality and peer relationships. There were no differences in age preferences, gifted and average students did not differ in the activities they performed during their time with their peers. Sociometric status in the classroom is the only feature in which gifted and average students are constantly significantly different (differences in friendship status are significantly influenced by giftedness, but differences in leadership status are significantly influenced by gender and type of 
school program as well as their giftedness. Research shows that age is more important for the quality of peer relationships than giftedness.

\section{METHODOLOGY}

\subsection{Research problem}

The research problem is the sociometric status of perceived gifted students in classroom and subject teaching. The assurance of accepting gifted students in a group of peers can be expressed by examining sociometric status by sociometric procedure. Gifted student-centred research tells us about their successful adjustment to peer groups, while some suggest adjustment problems.

\subsection{Objectives of the research}

In order to operationalize the research objective, the following research goals have been set:

1. identify the potential perceived giftedness of class and subject students

2. to determine the sociometric status of boys and girls in class and subject teaching

3. check that there is a correlation between the sociometric status of the student and his or her perceived giftedness

4. determine whether there is a difference in the sociometric status of the gifted students in the class and the sociometric status of the gifted students in the subject teaching

\subsection{Hypotheses}

It starts with the following hypotheses:

1. there is no statistically significant difference between the sociometric status of girls and boys in class and subject teaching

2. there is no statistically significant difference between the potential perceived giftedness of the students of the class teaching and the potential perceived gifted students of the subject teaching

3. there is no statistically significant correlation between the potential perceived giftedness of the student and the socio-metric status of the student 
4. there is no statistically significant difference between the sociometric status of potential perceived gifted students in the classroom and potential perceived gifted students of the subject

\subsection{Sample}

The study involved students of class teaching (4th grade, 10 years) and students of subject teaching (5th grade, 11 years) of one elementary school in Osijek - Baranja County in cooperation with the class teachers of the mentioned classes and the headmaster of the school. A total of 59 respondents participated in the survey, including 24 girls and 35 boys. Participation in the research is voluntary by the students and the results are anonymous.

\subsection{Variables}

For the purposes of this research, a dependent and a dependent variable will be used. The dependent variable is the sociometric status of the students in the class. The dependent variables are the students' perceived giftedness, the gender of the student, the age of the student, and the class that students attend.

\subsection{How to conduct research}

The survey was conducted in April 2018. The PRONAD Student Questionnaire found perceived gifted students by nominating those students who, in certain areas of giftedness, were the best, most prominent, and most noted according to the estimates of all students in the class, and the sociometric questionnaire determined the position of the individual in the group and the students were assessed on an emotional basis.

The sociometric procedure for determining the sociometric status by ranking technique was applied in the research. Students evaluated other students in the same class according to what degree they would like to socialize with them. Each student was given a list containing the names of all the other students in the class. Next to each student's name was a five-point Likert-type scale to determine the degree of liking. Sociometric status was determined by calculating the average grade a student received from other students 


\subsection{Procedures and instruments}

Two questionnaires were used in this study:

- questionnaire for students of PRONAD, authored by dr. sc. Ivan Koren ${ }^{\mathbf{1}}$

- sociometric questionnaire $^{2}$

\section{RESULTS}

1) Descriptive statistics of sociometric status

Table 1 contains the results on the sociometric status questionnaire for each individual respondent. The lowest score is 1.67 and the highest is 4.67.

Table 1. Individual scores on the sociometric status questionnaire from the lowest to the highest

\begin{tabular}{|c|c|c|c|c|c|c|c|}
\hline $\begin{array}{l}\text { Ordinal } \\
\text { number }\end{array}$ & The result & $\begin{array}{l}\text { Ordinal } \\
\text { number }\end{array}$ & The result & $\begin{array}{l}\text { Ordinal } \\
\text { number }\end{array}$ & The result & $\begin{array}{l}\text { Ordinal } \\
\text { number }\end{array}$ & The result \\
\hline 1. & 1.67 & 16. & 2.93 & 31. & 3.69 & 46. & 4.09 \\
\hline 2. & 1.69 & 17. & 3.20 & 32. & 3.70 & 47. & 4.10 \\
\hline 3. & 1.80 & 18. & 3.23 & 33. & 3.73 & 48. & 4.17 \\
\hline 4. & 2.27 & 19. & 3.27 & 34. & 3.73 & 49. & 4.20 \\
\hline 5. & 2.31 & 20. & 3.31 & 35. & 3.77 & 50. & 4.20 \\
\hline 6. & 2.53 & 21. & 3.31 & 36. & 3.77 & 51. & 4.20 \\
\hline 7. & 2.54 & 22. & 3.38 & 37. & 3.80 & 52. & 4.20 \\
\hline 8. & 2.60 & 23. & 3.40 & 38. & 3.85 & 53. & 4.23 \\
\hline 9. & 2.62 & 24. & 3.46 & 39. & 3.85 & 54. & 4.27 \\
\hline 10. & 2.69 & 25. & 3.54 & 40. & 3.91 & 55. & 4.27 \\
\hline 11. & 2.70 & 26. & 3.55 & 41. & 3.92 & 56. & 4.46 \\
\hline 12. & 2.87 & 27. & 3.60 & 42. & 4.00 & 57. & 4.60 \\
\hline 13. & 2.91 & 28. & 3.62 & 43. & 4.00 & 58. & 4.60 \\
\hline 14. & 2.92 & 29. & 3.62 & 44. & 4.00 & 59. & 4.67 \\
\hline 15. & 2.93 & 30. & 3.62 & 45. & 4.07 & & \\
\hline
\end{tabular}

1 The PRONAD Student Questionnaire for Finding and Identifying Students in Classroom (Attachment 1) is taken from: Koren, I. (1989) How to identify and identify a gifted student. Zagreb: Školske novine.

2 Sociometric Questionnaire for Examination of Sociometric Status of Students in Classroom (Annex 2) was adapted according to the template from: Majstrović, I. (2015) Sociometric status of gifted students in classrooms 


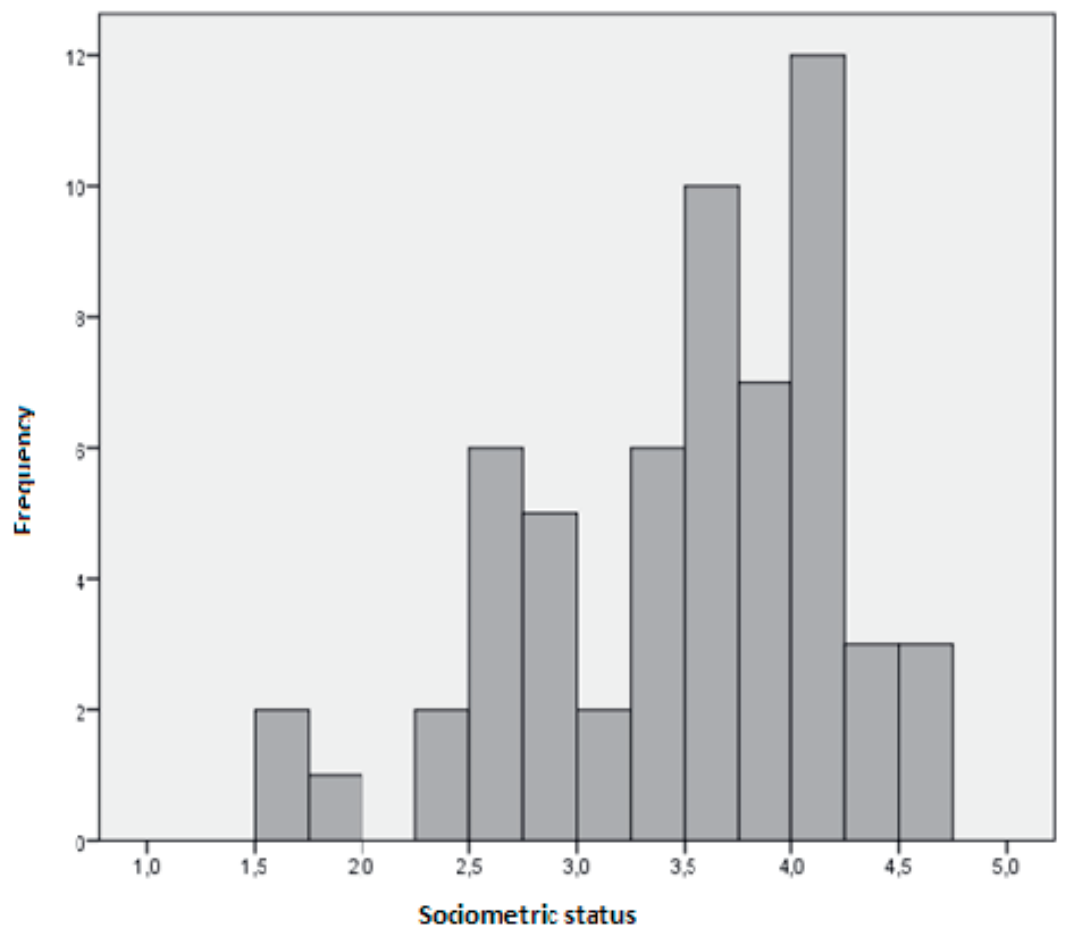

Figure 1. Distribution of sociometric status of students in research

2) Relationship between sociometric status and nomination on the PRONAD questionnaire

Correlation coefficients were calculated to determine the correlation between sociometric status as determined by the ranking technique and perceived ability in different areas of school achievement as determined by the naming technique (PRONAD-U questionnaire). Spearman's correlation coefficient was used, since the insight into the form of correlation among the variables revealed a nonlinear but monotonous trend of correlation.

Table 2. Spearman's correlation coefficients between the height of sociometric status and the number of nominations in different areas of school achievement on the PRONAD questionnaire

\begin{tabular}{llc}
\hline Which of your classmates... & rs & p \\
\hline knows the easiest and the fastest way to solve different difficult tasks? & .630 & $<.001$ \\
\hline shows the greatest interest in learning? & .680 & $<.001$ \\
\hline
\end{tabular}




\begin{tabular}{lcc}
\hline is the best public speaker? & -.681 & $<.001$ \\
\hline is the best in math? & .687 & $<.001$ \\
\hline draws or models the most beautiful? & .554 & $<.001$ \\
\hline has the best sense of humour? & .319 & .014 \\
\hline reads books most (except for school textbooks)? & .724 & $<.001$ \\
\hline writes the most beautiful songs and essays? & .635 & $<.001$ \\
\hline
\end{tabular}

Note. rs - Spearman correlation coefficient, $p$ - statistical significance.

The calculated Spearman correlation coefficients reveal that the correlations between sociometric status and the number of nominations on different sections of the PRONAD questionnaire are all statistically significant and positive. These are strongly expressed connections for all questions, except for the question "Who has the best sense of humour?", which is medium expressed. We conclude that greater sociometric status is associated with more nominations on the PRONAD questionnaire, for all areas of school achievement and humour. The highest correlation was found between sociometric status and nominations on the question "Who reads books most (except for school textbooks)?" $\left(\mathrm{r}_{\mathrm{s}}=.724, \mathrm{p}<0.001\right)$. The association between sociometric status and nominations on the question "Who has the best sense of humour?" was the least mentioned $\left(\mathrm{r}_{\mathrm{s}}=.319, \mathrm{p}=0.014\right)$. This rejected the second hypothesis, which assumes that there is no statistically significant correlation between the results of the sociometric questionnaire assessing each student's sociometric status and the results of the PRONAD-U questionnaire.

3) Difference in sociometric status of boys and girls

To determine the difference in sociometric status of boys and girls, a t-test for independent samples was performed. The descriptive data of the compared groups are in Table 3.

Table 3. Descriptive statistics of sociometric status for girls and boys

\begin{tabular}{lll}
\hline & $(\mathrm{M})$ & $(\mathrm{SD})$ \\
\hline Boys & 3.26 & 0.75 \\
\hline Girls & 3.77 & 0.61 \\
\hline Total & 3.49 & 0.73 \\
\hline
\end{tabular}

The Leven variance equality test found that the homoscedasticity condition was satisfied and Student's t-test was used. The results of the t-test show that girls have statistically significantly higher sociometric status than boys $(t(57)=-.2 .828$, $\mathrm{p}=.006)$. The effect was medium $(\mathrm{r}=0.35)$. This rejected the first hypothesis, which states that there is no statistically significant difference between the sociometric status of girls and boys. 
4) Difference in sociometric status of students who have been identified as gifted and those who have not been identified as gifted

To determine the difference in sociometric status of students who have been identified as gifted and those who have not been identified as gifted, a t-test for independent samples was performed. Descriptive data of the compared groups are provided in Table 4.

Table 4. Descriptive statistics on sociometric status for students with or without established giftedness

\begin{tabular}{llll}
\hline & $(\mathrm{M})$ & $(\mathrm{SD})$ & $\mathrm{N}$ \\
\hline Giftedness established & 4.12 & 0.38 & 14 \\
\hline No giftedness was determined & 3.30 & 0.71 & 45 \\
\hline Total & 3.49 & 0.73 & 59 \\
\hline
\end{tabular}

The Leven variance equality test found that the homoscedasticity condition was not satisfied, which is why the corrected data were used (Welch's t-test). The results of the t-test show that students who have been found gifted have a statistically significantly higher sociometric status than students who have not been gifted $(\mathrm{t}(41.687)=5.573, \mathrm{p}<.001)$. The effect was medium $(\mathrm{r}=0.48)$. This rejected the third hypothesis, which states that there is no statistically significant difference between the sociometric status of students who have been identified as gifted and those who have not been identified.

5) Difference in sociometric status of students in class and subject teaching

The statistical significance of the difference in sociometric status between the students of the class and subject teaching was determined by a t-test for independent samples. The descriptive data of the compared groups are in Table 5.

Table 5. Descriptive statistics on sociometric status of class and subject students

\begin{tabular}{llll}
\hline & $(\mathrm{M})$ & $(\mathrm{SD})$ & $\mathrm{N}$ \\
\hline Classroom teaching & 3.47 & 0.76 & 30 \\
\hline Subject teaching & 3.52 & 0.71 & 29 \\
\hline Total & 3.49 & 0.73 & 59 \\
\hline
\end{tabular}

The Leven variance equality test found that the homoscedasticity condition was satisfied. No statistically significant difference was found between class and subject students $(\mathrm{t}(57)=0.294, \mathrm{p}=.770)$. The second hypothesis, which predicts that there will be no difference between the students of the subject and class teaching, is confirmed.

6) Difference in the sociometric status of gifted students in class and subject teaching 
The statistical significance of the difference in sociometric status between students of the class and subject teaching who were gifted was determined by a t-test for independent samples. The descriptive data of the compared groups are in Table 6.

Table 6. Descriptive statistics on sociometric status for students of grade and subject teaching who have been identified as gifted

\begin{tabular}{lccc}
\hline & $(\mathrm{M})$ & $(\mathrm{SD})$ & $\mathrm{N}$ \\
\hline Classroom teaching & 4.09 & 0.40 & 7 \\
\hline Subject teaching & 4.14 & 0.39 & 7 \\
\hline Total & 4.12 & 0.38 & 14 \\
\hline
\end{tabular}

The Leven variance equality test found that the homoscedasticity condition was satisfied and Student's t-test was used. No statistically significant difference was found between the grade and subject teaching students who were gifted ( $t$ (12) $=-0.209, \mathrm{p}=.838$ ). The fourth hypothesis, which predicts that there will be no difference between the observed subgroups, is confirmed.

\section{DISCUSSION}

The results of the research showed that gifted students have a higher sociometric status than those who are not gifted. Popularity is also one of the claims that results from students' positive attitudes toward peers. The results of the research generally agree with the results of the aforementioned studies, according to which the sociometric status of the gifted is far better than the sociometric status of the average students. According to research that says girls are more adaptable to peer relationships than boys, we tested the first hypothesis in the study and came to the conclusion that a hypothesis saying that there was no statistically significant difference between girls 'and boys' sociometric status should be rejected because the results show that girls have a statistically significantly higher sociometric status than boys. These results are to be expected given that girls in the lower grades, as opposed to adolescence, are better adjusted than boys. Furthermore, the results reveal that the associations between sociometric status and the number of nominations on the different sections of the PRONAD questionnaire are all statistically significant and positive. These are strongly expressed connections for all questions, except for the question "Who has the best sense of humour?", which is medium expressed. We conclude that greater sociometric status is associated with more nominations on the PRONAD questionnaire, for all areas of school achievement and humour. This rejected the second hypothesis, which assumes that there is no statistically significant correlation between the results of the sociometric question- 
naire assessing each student's sociometric status and the results of the PRONAD-U questionnaire. The results of the study also found no statistically significant difference between upper and lower grade students, although social sensitivity in upper grades exists because upper grade students are already in their puberty. Thus, the second hypothesis, which predicts that there will be no difference between upper and lower grade students, is confirmed. Also, differences in lower and upper grades do not affect the sociometric status of students who have been identified as perceived potential giftedness and students who have not been identified as potential perceived giftedness. The fourth hypothesis, which predicts that there will be no difference between the observed subgroups, is confirmed.

\section{CONCLUSION}

Giftedness is characterized by exceptional skills for success in various fields. The surrounding in which children reside is a very important environment for children to learn to cooperate, behave and socialize. Gifted individuals of all ages notice at some stage in their lives that they are different from other peers and that they have to find their own ways to cope with many stressful situations in life because of the way they perceive the world around them and the depth of emotions they carry. Gifted children need the support and acceptance of adults, parents, families and those who work with them as teachers. Gifted children also feel the need to belong to a group of peers they hang out with, they want to be accepted and want to be part of the community regardless of their characteristics that differentiate them from their peers. However, they sometimes fail to have good social relationships with their peers. Their acceptance by peers is not only their merit, it also depends on the environment in which they struggle, but also on the way peers treat them, as well as the situations in which they participate. The bad situations they face come from lack of social acceptance. The conducted research shows that there is a strong and positive correlation between sociometric status and the number of nominations in different areas of school achievement on the PRONAD questionnaire. Therefore, children of high sociometric status will be more likely assessed as extremely skilled in a wide range of abilities. Respondents with established perceived potential giftedness have higher sociometric status than students who have not identified perceived potential giftedness. No difference was found between the students of the subject and class teaching, but the small sample limits the strength of the research, so the research should be extended to a larger number of respondents. The research makes a scientific contribution by confirming the positive sociometric status of gifted students and should be encouraged in educational institutions to create an appropriate environment for each individual, not just the gifted. 


\section{REFERENCES}

1. Bailey, C. L. (2007). Social and emotional needs of gifted students: What school counselors need to know to most effectively serve this diverse student population. Columbus, $\mathrm{OH}$.

2. Cohen, L., Manion, L. Morrison, K. (2007). Metode istraživanja u obrazovanju. Jastrebarsko: Slap.

3. Ford Inman, T., Kirchner, J. (2016). Parenting gifted children. Texas: Prufrock Press Inc. Waco

4. Kolak, A. (2010). Sociometrijski status učenika u razrednom odjelu i školskoj hijerarhiji. Pedagogijska istraživanja. 7 (2): 243-254

5. Koren, I. (1989). Kako prepoznati i identificirati nadarenog učenika. Zagreb: Školske novine.

6. Košir, K. \& Pečjak, S. (2005), Sociometry as a method for investigating peer relationships: what does it actually measure?, Educational Research, 47 (1): 127-144.

7. LaFontana, K. M. \& Cillessen, A. H. N. (2002). Children's interpersonal perceptions as a function of sociometric and peer perceived popularity, American Psychological Association, 35 (5): 635647

8. Majstrović, I. (2015). Sociometrijski status darovitih učenika u razrednim odjelima. Diplomski rad. Zagreb: Filozofski fakultet. Odsjek za pedagogiju.

9. Maksić, S. (1998). Peers'relations of gifted students, Porto: APEPICT-a, Porto, Portugal: 435-455

10. Mikas, D., Szirovitza, L. (2017). School Success, Gender and Sociometric Status of Students Coll. Antropol. 41 (4): 345-349.

11. Moreno, J. L. (1962). Osnovi sociometrije. Beograd: Savremena škola.

12. Pastuović, N. (1997). Osnove psihologije odgoja i obrazovanja. Zagreb: Znamen.

13. Peairs, K. F. (2010). The Social World of Gifted Adolescents: Sociometric Status, Friendship and Social Network Centrality, $\mathrm{PhD}$ Thesis, Duke University

14. Robinson, N. M. (2008). The social world of gifted children and youth. In Pfeiffer, S. I. (Ed.), Handbook of giftedness in children: psycho-educational theory, research, and best practices. New York: Springer.

15. Sampson, C. (2013). Social and emotional issues of gifted young children, APEX: The New Zealand Journal of Gifted Education [online], 18 (1): 1-10.

16. Wentzel, K. R. (2003). Sociometric Status and Adjustment in Middle School: A Longitudinal Study. Journal of Early Adolescence, 23 (1): 5-28.

17. Winner, E. (2005). Darovita djeca, mitovi i stvarnost. Buševac: Ostvarenje. 


\section{SOCIOMETRIJSKI STATUS DAROVITIH UČENIKA U RAZREDNOJ I PREDMETNOJ NASTAVI OSNOVNE ŠKOLE}

\section{SAŽETAK}

Darovita su djeca ona s iznadprosječnim sposobnostima za razliku od svojih vršnjaka. Lošiji sociometrijski status darovitih učenika često proizlazi iz nezadovoljenosti njihovih odgojno-obrazovnih potreba te činjenici da se njihovi interesi često ne poklapaju s interesima njihovih vršnjaka. Istraživanja su pokazala da popularnost i omiljenost učenika u skupini vršnjaka predstavlja važnost za uspjeh u budućnosti. Cilj je ovoga empirijskoga istraživanja bio utvrditi sociometrijski status potencijalnih percipiranih darovitih učenika razredne i predmetne nastave. Uzorak ispitanika bilo je 59 učenika razredne i predmetne nastave seoske sredine na području Osječko-baranjske županije. Rezultati istraživanja pokazali su da postoji snažna i pozitivna povezanost sociometrijskoga statusa i broja nominacija u različitim područjima školskoga postignuća te je ustanovljeno da učenici kojima je utvrđena potencijalna percipirana darovitost imaju veći sociometrijski status nego djeca kojima nije utvrđena potencijalna percipirana darovitost. Rezultati istraživanja mogli bi dati smjernice za provjeru prijašnjih teorijskih postavki i nadopunu postojećih ključnih faktora koji utječu na sociometriski status učenika u odgojnoobrazovnome sustavu. Također bi ovo istraživanje moglo biti poticaj za buduća istraživanja u ovome području.

Ključne riječi: daroviti učenici, sociometrijski status, međuvršnjački odnosi, razredni odjeli razredne i predmetne nastave 


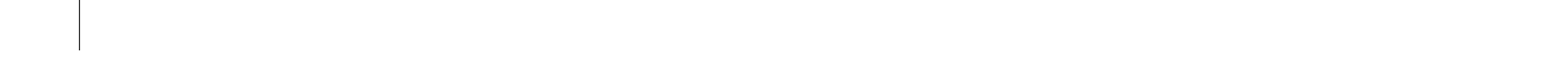

